\title{
Morphology of Two Eschaneustyla Species (Ciliophora, Urostylida), with Notes on Morphogenesis of Eschaneustyla lugeri
}

\author{
Yufan DENG ${ }^{1,2, *}$, Xiaoteng $\mathrm{LU}^{3, *}$, Jingbao $\mathrm{LI}^{4}$, Sang BA ${ }^{1}$, Thiago da Silva PAIVA ${ }^{5}$ \\ ${ }^{1}$ School of Sciences, Tibet University, Lhasa, China; ${ }^{2}$ The Key Laboratory of Biomedical Information Engineering Ministry of \\ Education, Department of Biology and Engineering, School of Life Science and Technology, Xi'an Jiaotong University, Xi'an, \\ China; ${ }^{3}$ Institute of Evolution and Marine Biodiversity, Ocean University of China, Qingdao, China; ${ }^{4}$ Key Laboratory for Space \\ Bioscience and Biotechnology, Institute of Special Environmental Biophysics, School of Life Sciences, Northwestern Polytechnical \\ University, Youyi Xilu 127, Xi'an, Shaanxi, China; ${ }^{5}$ Laboratório de Protistologia, Departamento de Zoologia, Instituto de Biologia, \\ Universidade Federal do Rio de Janeiro, Rio de Janeiro-RJ, Brazil
}

*Both authors contributed equally to this work.

Abstract. In this study, morphology of a Brazilian population of Eschaneustyla terricola Foissner, 1982 and a Chinese population of E. lugeri Foissner, Agatha \& Berger, 2002 were studied based on living observation and protargol impregnation. Several stages of morphogenesis in E. lugeri were reported and the most remarkable features are characterized as follows: (1) partly renewal of adoral zone of membranelles in the proter and the parental midventral cirri do not join the construction of the opisthe's oral primordium; (2) three or four buccal cirri each develop from one frontoventral cirral anlage and undulating membranes anlage generates two frontal cirri; (3) frontoventral cirral anlagen $n$ and $n-1$ develop de novo and in the frontoterminal cirral row, respectively; (4) intrakinetal development of marginal and dorsal kineties anlagen; (5) fusion of macronuclear nodules into a single mass.

Key words: Ciliates; infraciliature; ontogenesis; urostylid

\section{INTRODUCTION}

The hypotrichs $s . l$. are one of the most diverse and speciose ciliate groups with about 700 valid species de-

Address for correspondence: Sang Ba, School of Sciences, Tibet University, Lhasa 850000, China; Tel./Fax: +860891640 5211; E-mail: hbasang2003@aliyun.com

Thiago da Silva Paiva, Laboratório de Protistologia, Dept. de Zoologia, Inst. de Biologia, CCS, Universidade Federal do Rio de Janeiro - UFRJ. CEP: 21941-092 Ilha do Fundao, Rio de Janeiro, RJ, Brazil; Tel./Fax: +55 213938 6363; E-mail: tpaiva@biologia.ufrj.br; paivatds@gmail.com scribed so far (Berger 1999, 2006, 2008, 2011; Foissner et al. 2002; Foissner 2016). Recently, much work has been carried out on the morphological and molecular diversity of hypotrichs, helping to improve the knowledge on their phylogeny, even though it remains unresolved at various levels (Shao et al. 2011, 2013a, b, 2014; Li et al. 2013; Heber et al. 2014; Paiva et al. 2014, 2016; Jo et al. 2015; Luo et al. 2015; Singh and Kamra 2015; Bharti et al. 2016; de Castro et al. 2016, 2017; Wang et al. 2016, 2017; Chen et al. 2017).

Among hypotrichs, the urostylid genus Eschaneustyla, established by Stokes (1886) with E. brachytona 
as the type species, is mainly characterized by the following features: (1) several frontal cirri arranged in two or more rows (multi-corona); (2) more than two frontoterminal cirri forming distinct row; (3) transverse cirri absent; (4) four dorsal kineties; (5) number of caudal cirri distinctly increased. Since then, two other species were established in Eschaneustyla, namely E. terricola Foissner, 1982 and E. lugeri Foissner, Agatha and Berger, 2002. Due to the lack of thorough studies, Eschaneustyla has been placed in rather different taxa or even misclassified repeatedly in the past (for revision, see Berger 2006). Based on the similarity in frontal ciliature (multi-corona) and midventral complex (composed of midventral rows only), Berger (2006) assigned Eschaneustyla in Epiclintidae alongside Epclintes, but he claimed that further data are needed to evaluate this classification. Lyu et al. (2018) found that Eschaneustyla and Epiclintes are distantly separated in phylogenetic trees, and classified Eschaneustyla as incertae sedis within Urostylida.

This study contributes to the knowledge on Eschaneustyla by characterizing a population of $E$. terricola from the Brazilian Amazonia, and another of E. lugeri from China. The divisional morphogenesis of the latter is described.

\section{MATERIALS AND METHODS}

\section{Sampling and identification}

Eschaneustyla terricola was obtained from samples of soil with litter collected from a forest area $\left(3^{\circ} 05^{\prime} \mathrm{S} 59^{\circ} 58^{\prime} \mathrm{W}\right)$ in Manaus, Amazonas, Brazil, in November 2014, and E. lugeri was obtained from the moss scrapped from a damp rock in Mount Zhongnan $\left(33^{\circ} 59^{\prime} \mathrm{N}, 108^{\circ} 59^{\prime} \mathrm{E}\right), \mathrm{Xi}$ 'an, China, in March 2016.

Ciliates were made to excyst by employing the non-flooded Petri dish method (Foissner, 1992). Raw cultures were established at room temperature (about $24^{\circ} \mathrm{C}$ ) using Petri dishes filled with filtered soil percolate. Some squashed wheat grains were added to support microbial growth. Although we could not establish a clonal culture for Eschaneustyla terricola and E. lugeri, the specimens used for morphological and molecular analyses were very likely conspecific because no other Eschaneustyla-like morphospecies were found during live observations and in the protargol preparations. This population of E. lugeri is identical with Eschaneustyla lugeri KY874005 sequenced by Lyu et al. (2018).

Isolated ciliate cells were observed in vivo using bright-field and differential interference contrast microscopy. Infraciliature was revealed using the protargol preparation method of Wilbert (1975). Counts and measurements of impregnated specimens were performed at a magnification of $1250 \times$. Drawings of stained cells were made with the help of a camera lucida. To illustrate the changes occurring during morphogenetic process, old (parental) structures are depicted by contour, whereas new ones are shaded black (Shao et al. 2007, 2012). Terminology follows Berger (2006) and systematics is mainly based on Adl et al. (2012) (for the use of 'Hypotrichia') and Lynn (2008) (for classification under subclass-level).

Voucher slides containing both species were deposited in Lab of Protozoology, Xi'an Jiaotong University, China, with E. terricola under the registration number LEO20150421011/2 and E. lugeri under the registration numbers DYF2016031701A-G.

\section{RESULTS}

\section{Morphology of Brazilian population of Eschaneusty- la terricola Foissner, 1982 (Figs 1A, B, 2D, E; Table 1)}

Body outline long oval with anterior end broadly rounded and posterior end narrowly rounded, very flexible but not contractile, size in vivo about $170 \times 50 \mu \mathrm{m}$. Contractile vacuole at left body margin slightly ahead of mid-body (Fig. 2E). Cortical granules colorless, about $0.5 \mu \mathrm{m}$ across, grouped or arranged in longitudinally oriented short rows throughout body (Fig. 2D). Cytoplasm colorless. 59-106 macronuclear nodules, scattered throughout cell body; one to five micronuclei (Fig. 1B). Cirral pattern and number of cirri of usual variability, basically as depicted in Fig. 1A, B. Adoral zone of membranelles (AZM) with 35-47 membranelles of ordinary composition, occupies $c a .30 \%$ of body length in protargol preparation; DE-value $c a$. 0.32. Paroral and endoral short, slightly curved and intersected. Invariably one buccal cirrus. Five to seven oblique cirral rows in frontal field, each composed of three to five, usually four cirri, except the anteriormost one which comprises seven to nine cirri. Frontal cirrus isolated in left anterior corner of adoral zone, slightly enlarged. Anteriormost cirri in anteriormost two rows as large as the frontal cirri isolated in right anterior corner of adoral zone. Two to four long cirral rows in postoral region extend to about posterior third of cell. Frontoterminal row composed of 20-28 cirri, commences near distal end of AZM and terminates at or behind mid-body (on average $60 \%$ of body length). One left and one right marginal row; left row slightly curved rightwards anteriorly (Fig. 1A). Transverse cirri absent (Fig. 1A). Invariably four rows of dorsal kineties with rows 1 and 3 slightly shortened anteriorly, each with two to four caudal cirri, thus eight to 14 in total (Fig. 1B). Length of dorsal bristles is about $5 \mu \mathrm{m}$. 


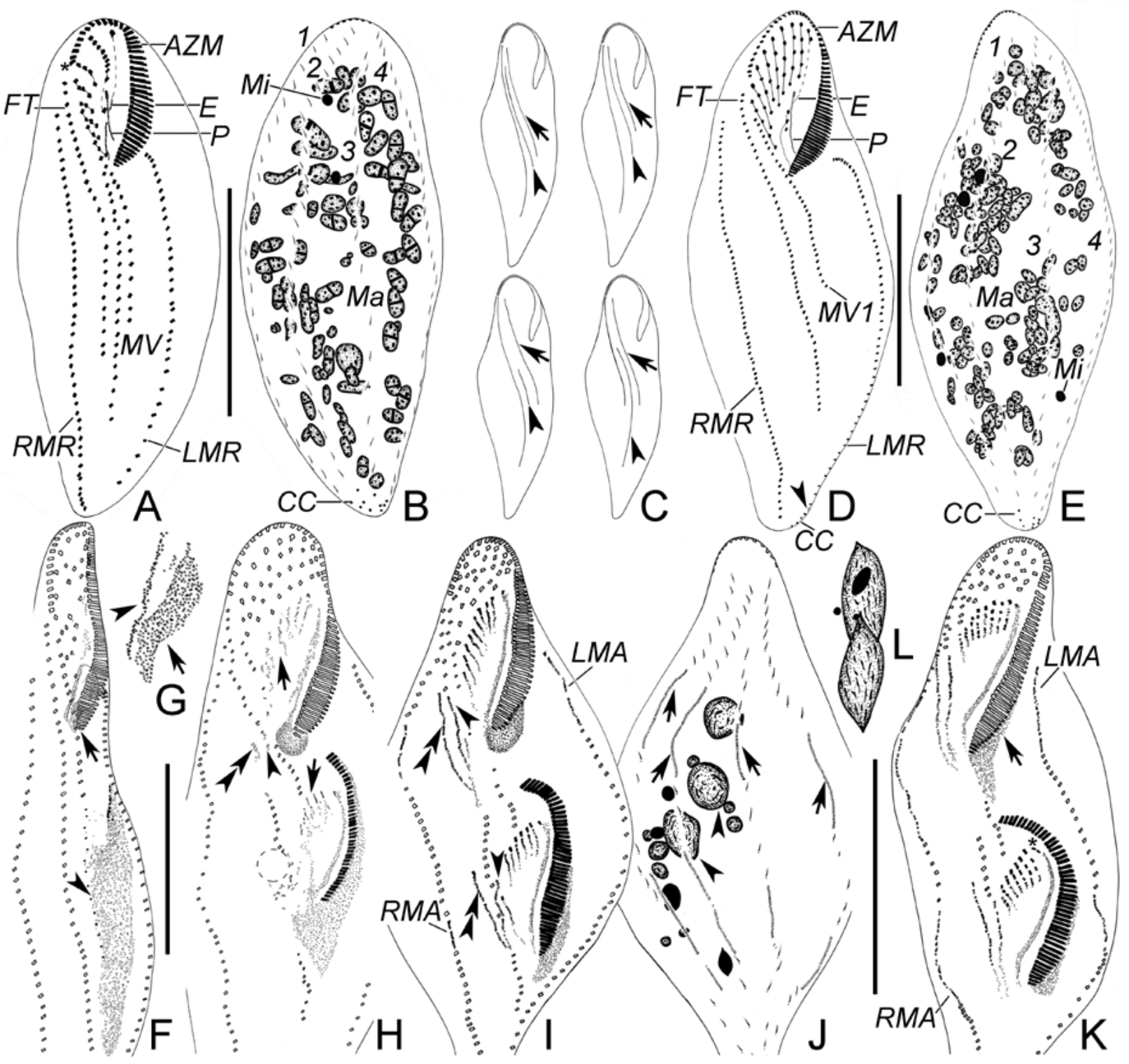

Fig. 1. Eschaneustyla terricola $(\mathbf{A}, \mathbf{B})$ and E. lugeri $(\mathbf{C}-\mathbf{E})$ during interphase, and E. lugeri during morphogenesis $(\mathbf{F}-\mathbf{L})$, after protargol impregnation. (A, B) Ventral and dorsal view of same specimen, showing ciliature. Cirri formed from same anlage were connected by solid line. Asterisk denotes the distal end of AZM. (C) Schematic representations of midventral-complex of four E. lugeri specimens with two long midventral rows. Arrows and arrowheads denote midventral rows 1 and 2, respectively. (D, E) Ventral and dorsal view of same specimen, showing typical infraciliature. Cirri formed from same anlage were connected by solid line. Two leftmost cirri develop from anterior part of undulating membranes anlage (dotted line). (F) Ventral view of an early divider that twisted a little at the anterior end, to show the oral primordia of proter (arrow) and opisthe (arrowhead). (G) Enlarged image of proter's oral primordium (arrow) and undulating membranes anlage (arrowhead) of the individual shown F. Note that the former develops in deep of the cortex while the latter develops in the surface. (H) Ventral view of an early divider to show the frontoventral cirral anlagen (arrows). Arrowhead denotes the penultimate frontoventral cirral anlage which forms midventral row 1. Double-arrowhead denotes the frontoventral cirral anlage $\mathrm{n}$ that develops into frontoterminal row. Dashed circle represents the flurry area due to the hyperchromatism after protargol impregnation. (I, J) Ventral and dorsal view of an early divider to show the frontoventral cirral anlagen. Arrows and arrowheads in I mark the penultimate and the last frontoventral cirral anlagen, respectively. Note that marginal anlagen and dorsal kineties anlagen (arrows in J) develop intrakinetally. Macronuclear nodules are fusing (arrowheads in J). (K) Ventral view of a middle divider. Arrow marks the partly renewed adoral zone of membranelles of proter. Asterisk denotes two leftmost frontal cirri developed from the undulating membranes anlage. L. Nuclear apparatus of the same specimen as shown in K. Note that macronuclear nodules are fusing into a single mass. AZM, adoral zone of membranelles; CC, caudal cirri; E, endoral; FT, frontoterminal row; LMA, left marginal anlage; LMR, left marginal row; Ma, macronuclear nodules; Mi, micronuclei; MV, midventral row; MV 1, midventral row 1; 1-4, dorsal kineties 1-4; P, paroral; RMA, right marginal anlage; RMR, right marginal row. Scale bars: $100 \mu \mathrm{m}$ $(\mathrm{A}, \mathrm{B}, \mathrm{D}, \mathrm{E}) ; 70 \mu \mathrm{m}(\mathrm{F}-\mathrm{L})$. 


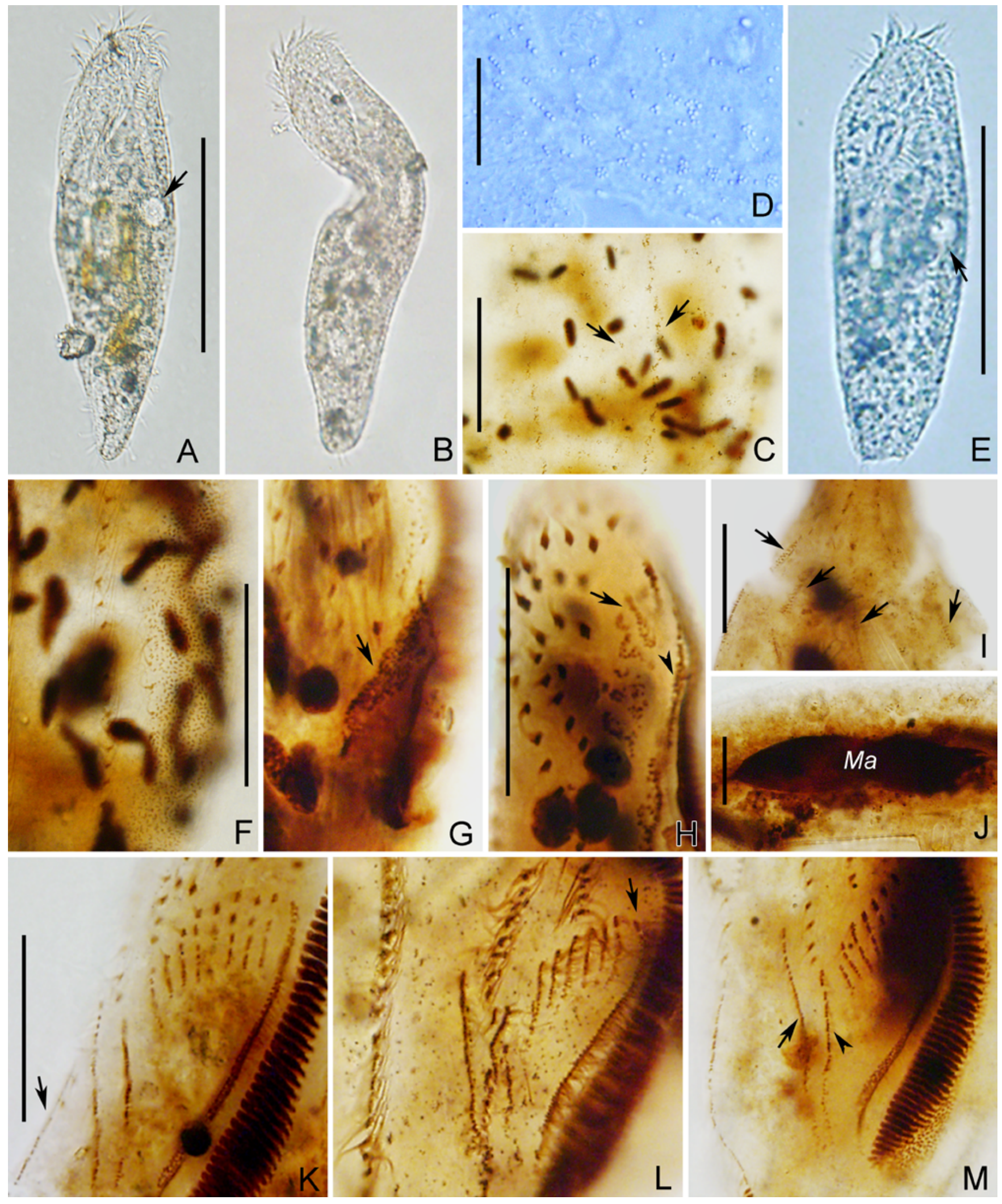




\section{Morphology of Chinese population of Eschaneus- tyla lugeri Foissner, Agatha and Berger, 2002 (Figs 1C-E, 2A-C; Table 1)}

Body outline elongate elliptical and often slightly sigmoidal with anterior end broadly rounded and posterior end narrowly rounded, very flexible but not contractile, size in vivo about $200 \times 60 \mu \mathrm{m}$. Contractile vacuole at left body margin slightly ahead of mid-body (Figs 2A, B). Cortical granules were failed to observe during living observation, but globular extrusomes were found after protargol impregnation. Extrusomes arranged around cirri and dorsal bristles, and irregularly scattered (Fig. 2C). Cytoplasm colorless, without conspicuous inclusions (Figs 2A, B). Nuclear apparatus occupying whole cell body, composed of 97-149 macronuclear nodules and three to 11 micronuclei (Fig. 1E). Cirral pattern and number of cirri of highly variability. AZM with 47-74 membranelles of ordinary composition, occupies $20 \%-37 \%$, on average $28 \%$ of body length (DE-value on average 0.42 ). 25-43 frontal cirri form distinct short rows composed of 4 or 5 cirri each, except the leftmost one that composed of only two cirri. Paroral and endoral intersect optically after protargol impregnation. Usually three or four buccal cirri right of mid-portion of paroral (Fig. 1D). The majority of the specimens observed have one long, slightly oblique midventral row (as shown in Fig. 1D). However, a small number of specimens (about 4 in 60 specimens observed) have a cirral pattern composed of two long midventral rows: the left one (midventral row $1=\mathrm{MV} 1$ ) and the right one (midventral row 2 = MV2) (Fig. 1C). The length of MV2 could be as similar to that of MV1, or rather short. MV2 could commence at the same level as frontoterminal row, or slightly behind anterior end of frontoterminal row, or at around onethird of body length (Fig. 1C). Specimen on the lower right in Fig. 1C shows a rather special cirral pattern that
MV2 terminates near rear body end as frontoterminal row in other specimens, whereas frontoterminal row terminates quite ahead. One left and one right marginal row, left row distinctly curved rightwards anteriorly; transverse cirri absent (Fig. 1D). Usually four rows of dorsal kineties, each with one to three, thus totally seven to 11 caudal cirri (Fig. 1E). Length of dorsal bristles is about $5 \mu \mathrm{m}$.

\section{Morphogenesis in Eschaneustyla lugeri (Figs 1F-L, 2F-M)}

Stomatogenesis. In the proter, the oral primordium commences in deep of the cortex independently, at around the proximal portion of AZM. Undulating membranes anlage that develops on the surface found to the right of oral primordium at the same time (Figs 1F, G; $2 \mathrm{G})$. Specimen in Fig. 2G somewhat twisted at anterior portion, thus the undulating membranes anlage presented to the left of the oral primordium. Parental undulating membranes not observed in this stage, we speculate that it disorganized into undulating membranes anlage. Parental buccal cirri might be absorbed in earlier stage due to their absence in this stage. Stomatogenesis of the opisthe commences with the proliferation of basal bodies around and on the left of midventral row 1, in which posterior cirri gradually absorbed (parental cirri become smaller without any sign of disaggregation, thus absorption is supposed) (Figs 1F, 2F).

The proter's oral primordium subsequently moves to the proximal end of AZM and develops in the shape of a round concavity. The central part still remains in the depth of the cortex while the surrounding portion gradually migrates to the surface (Fig. 1H). Basal bodies then move along the left margin of AZM and engage in the renewal of membranelles with dissolving of parental membranelles (Fig. 1I). Undulating membranes anlage elongates anteriorly and connects with the oral primordium at the posterior end (Figs $1 \mathrm{H}, \mathrm{I} ; 2 \mathrm{H}$ ).

Fig. 2. Photomicrographs of Eschaneustyla lugeri $\mathbf{( A , ~ B ) ~ a n d ~ E . ~ t e r r i c o l a ~}(\mathbf{D}, \mathbf{E})$ in life and E. lugeri after protargol impregnation $(\mathbf{C}, \mathbf{F}-\mathbf{M})$. (A, B) Representative individuals. Arrow in A denotes the contractile vacuole. (C) Dorsal side to show the arrangement of extrusomes (arrows). (D) Arrangement of cortical granules. (E) Ventral view. Arrow marks the contractile vacuole. It should be noted that the specimen in $\mathrm{E}$ is slightly damaged, thus it doesn't present a narrowly rounded posterior end. (F-H) Ventral views of early dividers, to show the oral primordia of opisthe (F) and proter (arrow in G), the undulating membranes anlage (arrowhead in $\mathrm{H}$ ) and the frontoventral cirral anlagen (arrow in H). (I) Dorsal view of an early divider to show the intrakinetal development of dorsal kineties anlagen (arrows). (J) Fusion of macronuclear nodules. (K-M) Ventral views of middle dividers. Note that right marginal anlage develops intrakinetally (arrow in K). Arrow in $\mathrm{L}$ denotes the formation of the leftmost frontal cirri from frontoventral cirral anlage I. In M, arrow marks the frontoventral cirral anlage $\mathrm{n}$ that becomes the frontoterminal row and arrowhead depicts the penultimate frontoventral cirral anlage that forms midventral row 1, respectively. Ma, macronuclear nodules. Scale bars: $100 \mu \mathrm{m}$ (A, B, E); $40 \mu \mathrm{m}$ (C, F, G, I); $15 \mu \mathrm{m}$ (D, J); $25 \mu \mathrm{m}(\mathrm{H}, \mathrm{K}-\mathrm{M})$. 
Table 1. Morphometric data on Eschaneustyla terricola (te) and Eschaneustyla lugeri (lu), after protagol impregnation.

\begin{tabular}{|c|c|c|c|c|c|c|c|c|c|}
\hline Characteristic $^{\mathrm{a}}$ & Species & Min & Max & Mean & M & $\mathrm{SD}$ & SE & $\mathrm{CV}(\%)$ & $\mathrm{n}$ \\
\hline \multirow[t]{2}{*}{ Body, length } & te & 130.0 & 222.0 & 187.6 & 195.0 & 28.3 & 8.5 & 15.1 & 11 \\
\hline & lu & 164.0 & 348.0 & 261.8 & 261.5 & 54.0 & 10.2 & 20.6 & 28 \\
\hline \multirow[t]{2}{*}{ Body, width } & te & 50.0 & 90.0 & 69.3 & 70.0 & 11.9 & 3.6 & 17.2 & 11 \\
\hline & lu & 38.0 & 141.0 & 91.4 & 95.0 & 29.1 & 5.5 & 31.9 & 28 \\
\hline \multirow[t]{2}{*}{ Body length:width, ratio } & te & 1.9 & 3.3 & 2.7 & 2.8 & 0.4 & 0.1 & 13.2 & 11 \\
\hline & lu & 2.0 & 5.5 & 3.0 & 2.8 & 0.8 & 0.1 & 26.1 & 28 \\
\hline \multirow[t]{2}{*}{ Macronuclear nodules, number } & te & 59 & 106 & 75.4 & 68.0 & 15.3 & 4.6 & 20.3 & 11 \\
\hline & lu & 97 & 149 & 119.6 & 119.0 & 13.6 & 3.3 & 11.4 & 17 \\
\hline \multirow[t]{2}{*}{ Micronuclei, number } & te & 1 & 5 & 3.1 & 3.0 & 1.2 & 0.4 & 38.6 & 10 \\
\hline & lu & 3 & 11 & 5.9 & 5.0 & 2.1 & 0.5 & 35.5 & 21 \\
\hline \multirow[t]{2}{*}{ Anteriormost macronuclear nodule, length } & te & 5.5 & 16.0 & 9.5 & 9.5 & 3.3 & 1.0 & 34.1 & 11 \\
\hline & lu & 5.0 & 21.0 & 11.0 & 10.0 & 4.6 & 1.1 & 41.7 & 19 \\
\hline \multirow[t]{2}{*}{ Anteriormost macronuclear nodule, width } & te & 2.5 & 7.0 & 4.5 & 5.0 & 1.4 & 0.4 & 32.2 & 11 \\
\hline & lu & 3.0 & 10.0 & 5.3 & 5.0 & 2.0 & 0.4 & 36.7 & 19 \\
\hline \multirow[t]{2}{*}{ Anteriormost micronucleus, length } & te & 3.0 & 5.0 & 3.8 & 4.0 & 0.6 & 0.2 & 14.7 & 11 \\
\hline & lu & 3.0 & 10.0 & 6.1 & 6.5 & 2.0 & 0.5 & 33.3 & 19 \\
\hline \multirow[t]{2}{*}{ Anteriormost micronucleus, width } & te & 3.0 & 4.0 & 3.5 & 3.5 & 0.5 & 0.1 & 13.7 & 11 \\
\hline & lu & 3.0 & 8.0 & 5.3 & 5.0 & 1.6 & 0.4 & 30.1 & 19 \\
\hline \multirow[t]{2}{*}{ AE to first macronuclear nodule, distance } & te & 9.0 & 22.5 & 15.8 & 16.0 & 3.8 & 1.1 & 24.0 & 11 \\
\hline & lu & 16.0 & 35.0 & 23.8 & 26.0 & 5.8 & 1.3 & 24.5 & 19 \\
\hline \multirow[t]{2}{*}{ PE to rearmost macronuclear nodule, distance } & te & 8.0 & 27.5 & 17.2 & 18.0 & 6.2 & 1.9 & 36.0 & 11 \\
\hline & $\mathrm{lu}$ & 14.0 & 60.0 & 30.7 & 27.0 & 12.6 & 3.1 & 41.2 & 17 \\
\hline \multirow[t]{2}{*}{ Posteriormost macronuclear nodule, length } & te & 3.0 & 11.0 & 7.4 & 7.0 & 2.7 & 0.8 & 37.1 & 11 \\
\hline & lu & 5.0 & 14.0 & 8.7 & 8.0 & 2.5 & 0.6 & 29.0 & 17 \\
\hline \multirow[t]{2}{*}{ Posteriormost macronuclear nodule, width } & te & 3.0 & 6.5 & 4.5 & 4.0 & 1.2 & 0.4 & 26.2 & 11 \\
\hline & lu & 2.0 & 10.0 & 4.3 & 3.5 & 2.3 & 0.6 & 55.0 & 17 \\
\hline \multirow[t]{2}{*}{ Adoral membranelles, number } & te & 35 & 47 & 41.5 & 41.0 & 3.4 & 1.0 & 8.3 & 11 \\
\hline & lu & 47 & 74 & 61.2 & 62.0 & 5.7 & 1.1 & 9.3 & 25 \\
\hline \multirow[t]{2}{*}{ Frontal cirri, number } & te & 3 & 3 & 3.0 & 3.0 & 0.0 & 0.0 & 0.0 & 11 \\
\hline & lu & 25 & 43 & 35.5 & 35.5 & 4.5 & 0.9 & 12.7 & 24 \\
\hline \multirow[t]{2}{*}{ Buccal cirri, number } & te & 1 & 1 & 1.0 & 1.0 & 0.0 & 0.0 & 0.0 & 11 \\
\hline & lu & 3 & 4 & 3.3 & 3.0 & 0.5 & 0.1 & 14.3 & 25 \\
\hline AE to proximal end of AZM, distance & lu & 38.0 & 99.0 & 77.3 & 78.0 & 15.7 & 3.1 & 20.3 & 25 \\
\hline AE to distal end of AZM, distance & lu & 12.0 & 58.0 & 33.4 & 33.0 & 10.1 & 2.0 & 30.4 & 25 \\
\hline DE value & lu & 0.3 & 0.59 & 0.42 & 0.42 & 0.1 & 0.0 & 16.7 & 25 \\
\hline AE to paroral, distance & lu & 23.0 & 50.0 & 38.3 & 40.0 & 6.3 & 1.3 & 16.4 & 22 \\
\hline Paroral, length & lu & 21.0 & 43.0 & 33.4 & 33.0 & 5.3 & 1.1 & 15.8 & 22 \\
\hline AE to first buccal cirrus, distance & lu & 30.0 & 64.0 & 49.0 & 51.0 & 7.5 & 1.6 & 15.3 & 21 \\
\hline AE to last buccal cirrus, distance & lu & 36.0 & 75.0 & 59.2 & 62.0 & 8.7 & 1.9 & 14.7 & 21 \\
\hline \multirow[t]{2}{*}{ Frontoterminal row, number of cirri } & te & 20 & 28 & 25.1 & 25.5 & 3.0 & 0.9 & 11.9 & 10 \\
\hline & lu & 30 & 60 & 49.5 & 50.0 & 6.9 & 1.4 & 13.9 & 23 \\
\hline \multirow[t]{2}{*}{ RMR, number of cirri } & te & 39 & 57 & 45.6 & 45.5 & 5.2 & 1.6 & 11.4 & 10 \\
\hline & lu & 41 & 78 & 58.4 & 59.0 & 7.9 & 1.8 & 13.6 & 20 \\
\hline
\end{tabular}




\begin{tabular}{|c|c|c|c|c|c|c|c|c|c|}
\hline \multirow[t]{2}{*}{ LMR, number of cirri } & te & 32 & 45 & 39.0 & 39.0 & 5.0 & 1.6 & 12.8 & 10 \\
\hline & lu & 46 & 61 & 52.2 & 53.0 & 4.0 & 0.9 & 7.6 & 20 \\
\hline \multirow[t]{2}{*}{ Midventral rows, number } & te & 8 & 9 & 8.6 & 9.0 & 0.5 & 0.2 & 6.2 & 9 \\
\hline & lu & 1 & 2 & 1.1 & 1.0 & 0.3 & 0.1 & 28.4 & 37 \\
\hline MV1, number of cirri & lu & 21 & 37 & 30.7 & 31.0 & 4.2 & 0.9 & 13.7 & 23 \\
\hline MV2, number of cirri & lu & 5 & 33 & 23.5 & 28.0 & 13.0 & 6.5 & 55.2 & 4 \\
\hline AE to MV1, distance & lu & 24.0 & 75.0 & 47.6 & 47.0 & 11.0 & 2.3 & 23.1 & 22 \\
\hline PE to end of MV1, distance & lu & 80.0 & 177.0 & 134.7 & 131.0 & 27.4 & 6.0 & 20.3 & 21 \\
\hline AE to MV2, distance & lu & 60.0 & 119.0 & 79.3 & 69.0 & 26.9 & 13.5 & 34.0 & 4 \\
\hline PE to end of MV2, distance & lu & 26.0 & 189.0 & 130.0 & 152.5 & 72.3 & 36.1 & 55.6 & 4 \\
\hline $\mathrm{AE}$ to frontoterminal row, distance & lu & 21.5 & 62.0 & 40.0 & 40.0 & 8.3 & 1.8 & 20.8 & 21 \\
\hline \multirow[t]{2}{*}{ PE to end of frontoterminal row, distance } & te & 60.0 & 102.0 & 78.0 & 71.5 & 16.8 & 5.3 & 21.6 & 10 \\
\hline & lu & 41.0 & 106.0 & 69.0 & 68.0 & 17.7 & 4.0 & 25.7 & 20 \\
\hline AE to LMR, distance & lu & 42.0 & 96.0 & 72.0 & 74.0 & 12.0 & 2.5 & 16.7 & 23 \\
\hline AE to RMR, distance & lu & 23.5 & 85.0 & 53.7 & 54.0 & 14.3 & 3.1 & 26.7 & 21 \\
\hline PE to LMR, distance & lu & 5.0 & 21.0 & 11.7 & 10.5 & 4.7 & 1.2 & 39.8 & 16 \\
\hline PE to RMR, distance & lu & 1.0 & 16.5 & 7.1 & 6.0 & 4.4 & 1.1 & 62.9 & 15 \\
\hline Midventral rows with 3 or 4 cirri, number & te & 3 & 5 & 4.3 & 4.0 & 0.7 & 0.2 & 16.3 & 9 \\
\hline Midventral rows with 5 or more cirri, number & te & 4 & 6 & 4.2 & 4.0 & 0.7 & 0.2 & 15.8 & 9 \\
\hline Rearmost cirral row, number of cirri & te & 5 & 24 & 20.6 & 0.0 & 6.0 & 2.0 & 29.0 & 9 \\
\hline PE to rear end of midventral complex, distance & te & 30.0 & 56.0 & 46.4 & 51.0 & 10.1 & 3.4 & 21.7 & 9 \\
\hline \multirow[t]{2}{*}{ Caudal cirri, number } & te & 8 & 14 & 9.8 & 9.5 & 2.2 & 0.9 & 22.7 & 6 \\
\hline & lu & 7 & 11 & 9.6 & 10.0 & 1.1 & 0.3 & 11.3 & 16 \\
\hline \multirow[t]{2}{*}{ Dorsal kineties, number } & te & 4 & 4 & 4.0 & 4.0 & 0.0 & 0.0 & 0.0 & 8 \\
\hline & lu & 4 & 5 & 4.1 & 4.0 & 0.3 & 0.1 & 7.5 & 20 \\
\hline
\end{tabular}

${ }^{a}$ All measurements in $\mu \mathrm{m}$. CV - coefficient of variance in \%; Min - minimum value observed; Max - maximum value observed; Mean - arithmetic mean; $\mathrm{M}$ - median; SD - standard deviation; SE - standard error; $n$ - sample size; AE - anterior end of cell; PE - posterior end of cell; MV1 - midventral row 1 (= rightmost midventral row in Foissner et al. 2002, Berger 2006 and Kim et al. 2015); MV2, midventral row 2.

Membranelles begin to differentiate at the right anterior part of opisthe's oral primordium (Figs 1F, H). Meanwhile, undulating membranes anlage for the opisthe appears, with differentiation commencing at the anterior end to form the leftmost frontal cirri (Fig. 1H).

In the mid-to-late stage, renewal of posterior portion of parental AZM continues on, which will eventually result in a partly renewed AZM of the proter. It should be noted that except for the few most proximal membranelles replaced by the new structure, others only slightly renewed at left sides. Specimen observed reveals that residual oral primordium of the proter has all migrated to the surface by this stage. As for the opisthe, membranelles continue to differentiate posteriad. Note that two leftmost frontal cirri of the opisthe have already formed from frontoventral cirral anlage I (Fig. 1K).
Development of frontoventral cirri. In early dividers, posterior portion of the parental frontal cirri dissolve into basal bodies, which begin to form the frontoventral cirral anlagen of the proter (Figs $1 \mathrm{~F}, \mathrm{H} ; 2 \mathrm{H}$ ). A few frontoterminal cirri near proximal end of AZM disaggregate to develop the penultimate frontoventral cirral anlage. A small field of basal bodies, regarded as the frontoventral cirral anlage n, develop on the right side of frontoterminal row de novo. Opisthe's frontoventral cirral anlagen appear on the right side of frontoventral cirral anlage I. Due to the hypochromatism after protargol impregnation, a small field around frontoterminal row in mid-body region was difficult to see (dashed circle in Fig. 1H). Only a few cluttered basal bodies develop around this field. It is not known whether these basal bodies completely come from dissolving frontoterminal cirri (Fig. 1H). In the next stage, frontoventral cirral 
anlagen develop into distinct streaks and elongate posteriad in both daughter cells. About 9-11 frontoventral cirral anlagen, including the last and the penultimate anlagen, eventually formed (Figs 1I, 2L). In some filial products, several small anlagen formed on the left of penultimate frontoventral cirral anlage, and these anlagen will possibly be absorbed subsequently (Fig. 2L). In the mid-to-late stage, frontoventral cirral anlagen segment and cirri gradually formed. The rightmost and the penultimate frontoventral cirral anlage eventually develops into the new frontoterminal row and MV1 respectively, while the rest of frontoventral cirral anlagen each splits to form about 4-6 cirri (Figs 1K, 2K, M). Although late dividers not found, we could believe that formation and migration of new cirri, and absorption of old ones are the main events during the rest of the morphogenetic process.

Marginal and dorsal anlagen. Two separate marginal anlagen develop intrakinetally within both left and right marginal rows. Cirri adjacent to anterior end of each marginal row and cirri slightly behind mid-body differentiate to form these two anlagen, respectively (Figs 1I, K; 2K). These anlagen then increase in size and develop into new cirri that eventually replace the old ones.

During the formation of dorsal kineties, two anlagen develop intrakinetally in each parental row. These anlagen then elongate and develop into new structures, along with the incorporation or absorption of parental structures (Figs 1J, 2I).

Division of the nuclear apparatus. Macronuclear nodules fuse into many masses during early stage (Fig. 1J) and eventually fuse into a single mass that divides subsequently during mid-to-late stage (Figs 1L, 2J). Micronuclei divide mitotically during cell division (Fig. 1J).

\section{DISCUSSION}

\section{Identification}

Eschaneustyla terricola was described by Foissner (1982) based on live and protargol-impregnated specimens. Until the present study, two other populations have been reported, one by Eigner (1994), who identified it as E. brachytona and considered E. terricola as its junior synonym, and another by Foissner et al. (2002). Compared with the type population, the Brazilian population has a longer frontoterminal row (terminating behind mid-body vs. terminating at about buccal vertex) as in Eigner's (1994) population, and more macronuclear nodules (59-106 vs. 45-75). However, we consider these to be population-specific differences, as conspicuous variability among populations, perhaps due to cryptic speciation, has been noticed by Foissner et al. (2002). The most important difference consists of the cortical granules, which are colorless and arranged in groups or longitudinally oriented short rows in Brazilian population, while yellowish in the others. The colorless granules might be indicative that the Brazilian population belongs to E. brachytona, which is colourless (Stokes, 1886). However, it is not known if the limnetic E. brachytona, has actual colorless cortical granules or if the granules are absent. Thus, regarding the synonymy with E. terricola, we agree with Foissner et al. (2002) that confirmation must wait for new data of a limnetic Eschaneustyla, as the other known populations are terrestrial. Since most morphological characters of the Brazilian population are within the range of the original description, we consider it conspecific with E. terricola.

Eschaneustyla lugeri was described by Foissner et al. (2002) based on live and protargol-impregnated specimens, and one Korean population (Kim and Min 2015) has been reported after the original description. The Chinese population is virtually identical to the original population in terms of infraciliature and most living features, except for a greater number of macronuclear nodules (97-149 vs. 49-76), however such difference might be population-dependent. Rare specimens with two long midventral rows, namely MV1 (= rightmost midventral row in Foissner et al. 2002, Kim and Min 2015) and MV2 (= rightmost midventral row in our population), were found in Chinese population, indicating a level of variability. Since the Chinese population accords well with the type population in most features, their conspecificity is assumed.

\section{Morphogenesis in Eschaneustyla lugeri}

The most notable feature of Eschaneustyla lugeri is that the frontal area is densely covered by cirri forming distinct rows. Morphogenetic data shows that these cirri develop in the same way as midventral rows in other urostylids, i.e. two leftmost frontal cirri are formed by frontoventral cirral anlage I and the others are formed in rows of 4 or 5 cirri within frontoventral cirral anlagen II to $n-2$.

It is remarkable that proter's frontoventral cirral anlage $\mathrm{n}$, which eventually becomes frontoterminal row, 
develops de novo, while frontoventral cirral anlage n-1, which forms MV1, comes from dissolving parental frontoterminal cirri.

It also should be noted that the number of cirri formed by frontoventral cirral anlage II is about 4 . Therefore, the possibility is rather high that anterior 3 or 4 frontoventral cirral anlagen (excluding frontoventral cirral anlage I) contribute their last segments to form the buccal cirri. This was observed in Apokeronopsis bergeri (Li et al. 2008).

Hitherto, only one Eschaneustyla species, namely E. terricola, has been studied morphogenetically (Eigner 1994). Based on the current observation, these two species have several morphogenetic features in common: (1) the parental AZM is partly renewed at the proximal end; (2) the old undulating membranes completely disorganize into anlage; (3) marginal anlagen and dorsal anlagen develop intrakinetally within parental structures; (4) macronuclear nodules fuse into a single mass during morphogenetic process; and (5) many oblique frontoventral cirral anlagen appear during morphogenesis, and parental cirri contribute to the formation of proter's frontoventral cirral anlagen. These are also plesiomorphies occurring in many other urostyloids. Besides, based on the dividers depicted by Eigner (1994), we speculate that proter's frontoventral cirral anlagen $\mathrm{n}$ and $\mathrm{n}-1$ in E. terricola possibly share the same origins as those in E. lugeri, that anlage $\mathrm{n}$ develops de novo while $\mathrm{n}-1$ comes from parental frontoterminal cirri. We deduce that Eigner might misinterpret the origins of these two anlagen.

Meanwhile, some differences exist between Eschaneustyla lugeri and E. terricola: (1) anlage I develops into 2 frontal cirri in E. lugeri but only 1 cirrus in E. terricola; (2) in E. lugeri, oral primordium forms in the proter and engages in the renewal of membranelles, while no oral primordium is formed in proter and basal bodies from the dissolved parental undulating membranes and proximal membranelles contributes to the renewal of proximal membranelles in E. terricola.

Acknowledgements. This study was supported by Natural Science Foundation of China (31872190, 31660620); Conselho Nacional de Desenvolvimento Científico e Tecnológico (Universal 485974/2013-4), Brazil; and Programa de cooperação técnico científico e pedagógico (PROTEC UERJ-UEA), Brazil.

\section{REFERENCES}

Adl S. M., Simpson A. G., Lane C. E., Lukes J., Bass D., Bowser S. S., Brown M. W., Burki F., Dunthorn M., Hampl V., Heiss A., Hoppenrath M., Lara E., Le Gall L., Lynn D. H., McManus H., Mitchell E. A., Mozley-Stanridge S. E., Parfrey L. W.,
Pawlowski J., Rueckert S., Shadwick L., Schoch C. L., Smirnov A., Spiegel F. W. (2012) The revised classification of eukaryotes. J. Eukaryot. Microbiol. 59: 429-493

Berger H. (1999) Monograph of the Oxytrichidae (Ciliophora, Hypotrichia). Monogr. Biol. 78: 1-1080

Berger H. (2006) Monograph of the Urostyloidea (Ciliophora, Hypotricha). Monogr. Biol. 85: 1-1303

Berger H. (2008) Monograph of the Amphisiellidae and Trachelostylidae (Ciliophora, Hypotricha). Monogr. Biol. 88: 1-737

Berger H. (2011) Monograph of the Gonostomatidae and Kahliellidae (Ciliophora, Hypotricha). Monogr. Biol. 90: 1-741

Bharti D., Kumar S., Terza A. L. (2016) Rigidosticha italiensis n. gen., n. sp. (Ciliophora, Spirotricha), novel large hypotrich ciliate from the soil of Lombardia, Italy. Eur. J. Protistol. 56: 112-118

Chen X., Lu X., Luo X., Jiang J., Shao C., Al-Rasheid K. A. S., Warren A., Song W. (2017) The diverse morphogenetic patterns in spirotrichs and philasterids: Researches based on five-yearprojects supported by IRCN-BC and NSFC. Eur. J. Protistol. 61: 439-452

de Castro L. A. M., Küppers G. C., Fernandes N. M., Schlegel M., Paiva T. da S. (2016) Ontogeny and molecular phylogeny of Apoamphisiella vernalis reveal unclear separation between genera Apoamphisiella and Paraurostyla (Protozoa, Ciliophora, Hypotricha). PLoS One 11: e0155825

de Castro L. A. M., da Silva-Neto I. D., Paiva T. da S. (2017) Physiological reorganization in the hypotrich ciliate Apoamphisiella vernalis (Protista, Ciliophora, Hypotricha). Iheringia, Sér. Zool. 107: e2017012

Eigner P. (1994) Divisional morphogenesis and reorganization in Eschaneustyla brachytona Stokes, 1886 and revision of the Bakuellinae (Ciliophora, Hypotrichida). Eur. J. Protistol. 25: 462-475

Foissner W. (1982) Ökologie und Taxonomie der Hypotrichida (Protozoa: Ciliophora) einiger österreichischer Böden. Arch. Protistenk. 126: 19-143

Foissner W. (1992) Estimating the species richness of soil protozoa using the "non-flooded Petri dish method". In: Lee J. J. \& Soldo A. T. (ed.), Protocols in Protozoology, Society of Protozoologists, Lawrence. p. B-10.1-B-10.2

Foissner W., Agatha S., Berger H. (2002) Soil ciliates (Protozoa, Ciliophora) from Namibia (Southwest Africa), with emphasis on two contrasting environments, the Etosha region and the Namib desert. Part I: Text and line drawings. Part II: Photographs. Denisia 5: 1-1459

Foissner W. (2016) Terrestrial and semiterrestrial ciliates (Protozoa, Ciliophora) from Venezuela and Galápagos. Denisia 35: 1-912

Heber D., Stoeck T., Foissner W. (2014) Morphology and ontogenesis of Psilotrichides hawaiiensis nov. gen., nov. spec. and molecular phylogeny of the Psilotrichidae (Ciliophora, Hypotrichia). J. Eukaryot. Microbiol. 61: 260-277

Jo E., Jung J., Min G. S. (2015) Morphology and molecular phylogeny of two new brackish water ciliates of Bakuella (Ciliophora: Urostylida: Bakuellidae) from South Korea. J. Eukaryot. Microbiol. 62: 799-809

Kim J. H, Min G. S. (2015) New record of two soil ciliates (Ciliophora: Stichotrichia) from Korea. Korean J. Environ. Biol. 33: 383-389

Li L., Song W., Warren A., Al-Rasheid K. A. S., Roberts D., Yi Z., Al-Farraj S. A., Hu X. (2008) Morphology and morphogenesis of a new marine ciliate, Apokeronopsis bergeri nov. spec. (Ciliophora, Hypotrichida), from the Yellow Sea, China. Eur. J. Protistol. 44: 208-219 
Li F., Xing Y., Li J., Al-Rasheid K. A. S., He S., Shao C. (2013) Morphology, morphogenesis and small subunit rRNA gene sequence of a soil hypotrichous ciliate, Perisincirra paucicirrata (Ciliophora, Kahliellidae), from the shoreline of the Yellow River, North China. J. Eukaryot. Microbiol. 60: 247-256

Luo X., Gao F., Al-Rasheid K. A. S., Warren A., Hu X., Song W. (2015) Redefinition of the hypotrichous ciliate Uncinata, with descriptions of the morphology and phylogeny of three urostylids (Protista, Ciliophora). Syst. Biodivers. 13(5): 455-471

Lynn D. H. (2008). The Ciliated Protozoa. Characterization, Classification, and Guide to the Literature, 3rd ed. Springer, Dordrecht.

Lyu Z., Wang J., Huang J., Warren A., Shao C. (2018) Multigenebased phylogeny of Urostylida (Ciliophora, Hypotrichia), with establishment of a novel family. Zool. Scr. https://doi. org/10.1111/zsc. 12267

Paiva T. da S., de Albuquerque A. F. C., Borges B. do N., Harada M. L. (2014) Description and phylogeny of Tetrakeronopsis silvanetoi gen. nov., sp. nov. (Hypotricha, Pseudokeronopsidae), a new benthic marine ciliate from Brazil. PLoS One 9: e88954

Paiva T. da S., Shao C., Fernandes N. M., Borges B. do N., da Silva-Neto I. D. (2016) Description and phylogeny of Urostyla grandis wiackowskii subsp. nov. (Ciliophora, Hypotricha) from an estuarine mangrove in Brazil. J. Eukaryot. Microbiol. 63: 247-261

Shao C., Hu X., Warren A., Al-Rasheid K. A. S., Al-Quraishy S., Song W. (2007) Morphogenesis in the marine spirotrichous ciliate Apokeronopsis crassa (Claparède \& Lachmann, 1858) n. comb. (Ciliophora: Stichotrichia), with the establishment of a new genus, Apokeronopsis n. g., and redefinition of the genus Thigmokeronopsis. J. Eukaryot. Microbiol. 54: 392-401

Shao C., Gao S., Hu X., Al-Rasheid K. A. S., Warren A. (2011) Ontogenesis and molecular phylogeny of a new marine urostylid ciliate, Anteholosticha petzi n. sp. (Ciliophora, Urostylida). J. Eukaryot. Microbiol. 58: 254-265

Shao C., Song W., Al-Rasheid K. A. S., Berger H. (2012) Redefinition and reassignment of the 18-cirri genera Hemigastrostyla, Oxytricha, Urosomoida, and Actinotricha (Ciliophora, Hypotri- cha), and description of one new genus and two new species. Acta Protozool. 50: 263-287

Shao C., Ding Y., Al-Rasheid K. A. S., Al-Farraj S. A., Warren A., Song W. (2013a) Establishment of a new hypotrichous genus, Heterotachysoma n. gen. and notes on the morphogenesis of Hemigastrostyla enigmatica (Ciliophora, Hypotrichia). Eur. J. Protistol. 49: 93-105

Shao C., Pan X., Jiang J., Ma H., Al-Rasheid K. A. S., Warren A., Lin X. (2013b) A redescription of the oxytrichid Tetmemena pustulata (Müller, 1786) Eigner, 1999 and notes on morphogenesis in the marine urostylid Metaurostylopsis salina Lei et al., 2005 (Ciliophora, Hypotrichia). Eur. J. Protistol. 49: 272-282

Shao C., Chen L., Pan Y., Warren A., Miao M. (2014) Morphology and phylogenetic position of the oxytrichid ciliates, Urosoma salmastra (Dragesco and Dragesco-Kerneis, 1986) Berger, 1999 and U. karinae sinense nov. sspec. (Ciliophora, Hypotrichia). Eur. J. Protistol. 50: 593-605

Singh J., Kamra K. (2015) Morphology and molecular phylogeny of an Indian population of Cyrtohymena citrina (Ciliophora, Hypotricha), including remarks on ontogenesis of UrosomoidaNotohymena-Cyrtohymena group. Eur. J. Protistol. 51: 280-289

Stokes A. C. (1886) Some new hypotrichous infusoria. Proc. Am. phil. Soc. 23: 21-30, 1 plate

Wang J., Lyu Z., Warren A., Wang F., Shao, C. (2016) Morphology, ontogeny and molecular phylogeny of a novel saline soil ciliate, Urosomoida paragiliformis n. sp. (Ciliophora, Hypotrichia). Eur. J. Protistol. 56: 79-89

Wang J., Li L., Warren A., Shao C. (2017) Morphogenesis and molecular phylogeny of the soil ciliate Rigidohymena quadrinucleata (Dragesco and Njine, 1971) Berger, 2011 (Ciliophora, Hypotricha, Oxytrichidae). Eur. J. Protistol. 60: 1-12

Wilbert N. (1975) Eine verbesserte Technik der Protargolimprägnation für Ciliaten. Mikrokosmos 64: 171-179

Received on $17^{\text {th }}$, December, 2017; revised on $27^{\text {th }}$ April 2018; accepted on $1^{\text {st }}$ May, 2018 